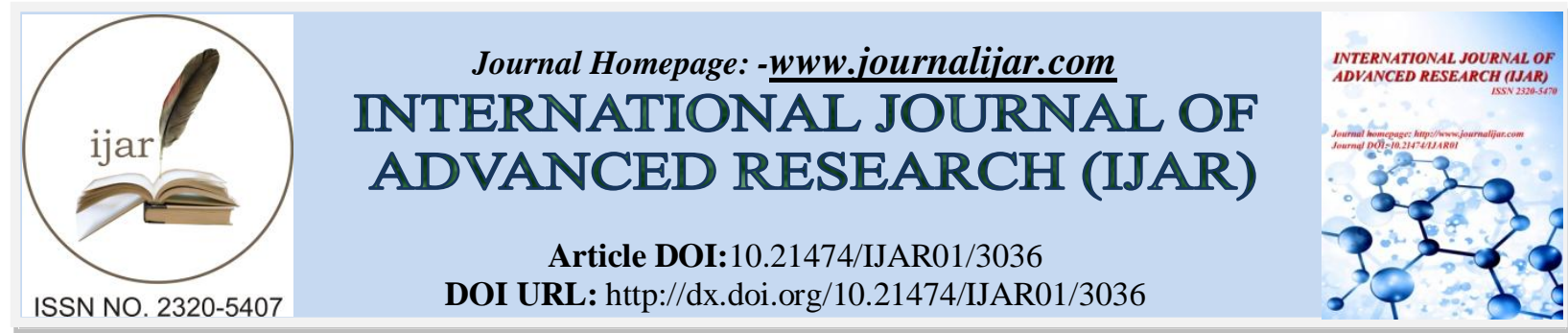

RESEARCH ARTICLE

\title{
INTEGRATION OF BEEF CATTLE BREEDING WITH CROP FARMING AT SUSTAINABLE RICEFIELD IN JEMBER REGENCY, EAST JAVA
}

Nantil B.E.S ${ }^{1}$, Zaenal Fanani ${ }^{2}$, Hari Dwi Utami ${ }^{2}$ and Moch Nasich ${ }^{2}$.

1. Postgraduate Program Doctor Students of Animal Husbandry, Brawijaya University.

2. Lecturer of Animal Husbandry, Brawijaya University.

\section{Manuscript Info}

Manuscript History

Received: 30 November 2016

Final Accepted: 28 December 2016

Published: January 2017

Key words:-

agriculture integration, sustainability, organization, beef cattle.

\section{Abstract}

The objective of this research was to analyze the sustainability status of the dimensions of economy, ecology, technology, and society, as well as organization in the integrated system of beef cattle breeding and crop farming in Jember Regency of East Java. Some analyses were included in this research, such as Analysis of Cost and Income, Analysis of Linear Programming, Analysis of Averagely Differential Rate (t-test), and Analysis of Sustainability. Result of research showed several findings. (1) The contribution of beef cattle breeding to the income of farmers/breeders was $8.18 \%$ but it was still smaller than the contribution of soybean farming with $31.13 \%$, corn with $27.59 \%$, and rice with $33.10 \%$. In average, the cost for cattle feed was spent for Rp.2,575,000.- Workers who must look for greens, provide drinks to the cattle, clean the stall, and others, were valued as Rp.1,350,000.-. The biggest component of the cost in breeding work was the price of the calf that averagely reached Rp.8,000,000.-- The sale price of the harvested calf could attain Rp.16,250,000.-. The income rate of breeding work was then around Rp.3,482,000.-. (2) Integration betwen beef cattle breeding and crop farming at research area could be made into optimum under several conditions. Soybean was planted at 5.381 Ha land. Both corn and rice were planted at $6.667 \mathrm{Ha}$ land. The maintained cattle should be 21 heads. The use of crop seed must be reduced, precisely $269 \mathrm{~kg}$ for soybean, $269 \mathrm{~kg}$ for corn, and $333 \mathrm{~kg}$ for rice. The use of Urea and organic fertilizers during Rainy Season I could be suppressed into the range between $1,849 \mathrm{~kg}$ and $3,333 \mathrm{~kg}$. In other hand, the capital that needed to prepare for each planting season might be reduced to Rp.83,373,340.- ; Rp.109,840,000.- dan Rp.87,426,666.-. (3) If the optimum condition could be attained by farmers/breeders, then farmers' income in the research area would improve to Rp.531,085,000.- per year. This increment was very significant if compared to the actual condition of farmers' income, that reaching at Rp.486,553,100,-. Therefore, the implementation of optimal condition scenario was very recommended to be applied at research area. (4) The model of the optimization and sustainability of agribusiness with the integration system between beef cattle breeding and crop farming was important as cornerstone in formulating the policies for the favor of breeders. The policies kept breeders to apply 
sustainable integration system. The combination of five dimensions of sustainability was used to measure the sustainability of agribusiness that involved the integration system between beef cattle breeding and crop farming. In whole, based on five dimensions of sustainability, then the agribusiness work with integration system between beef cattle breeding and crop farming at research area had the sustainability index rate of 42.40. This index showed that agribusiness work was less sustainable. Dimension with the worst sustainability index, and must be seriously attended, included the dimension of technology and infrastructure, and also the dimension of law and organization.

Copy Right, IJAR, 2016,. All rights reserved.

\section{Introduction:-}

Lower income of the farmers was caused by many factors. Among others were (1) limited ownership of farming land per farming household (RTP), with a width less than 0.50 ha, which should be not economically profitable for farming; (2) the declining land productivity due to strictly land intensification without land conservation; and (3) the relatively low price of farming product, especially during great harvest. Dealing with problems, then the integrated farming system comprising of rice, palawija, and beef cattle breeding, should be very relevant alternative to the existing problem-solving. Theoretically, integrated farming system could be functioned to conserve land fertility and to improve farming efficiency by utilizing the production input from inside the work (internal input). Rice farming might utilize the dung as the substitution to the synthetic fertilizers. Beef cattle breeding could use straw and other byproducts as the feed. Therefore, integrated farming system between rice and cattle would reduce the use outside input (low external output) which kept the system more efficient.

\section{Study Method:-}

\section{Sample of Research:-}

The population of research was farmers who applied one-year planting pattern involving soybean, corn and rice. These farmers also owned and bred beef cattle.

\section{Method of Data Analysis:-}

Some analysis methods were used. Each was described as following.

(1) Analysis of Cost and Income

$$
\begin{aligned}
\pi=\mathrm{TR} & -\mathrm{TC} \quad \text { or } \\
\pi & =\sum_{i=1}^{n} Q i P i-\sum_{j=1}^{m} X j P j
\end{aligned}
$$

Note:-

$\pi \quad=\quad$ Profit obtained from the integration of crop farming + beef cattle breeding

$\mathrm{TR}=$ Earning derived from the integration of crop farming + beef cattle breeding

$\mathrm{TC}=$ Expense required in the integration of crop farming + beef cattle breeding

$\mathrm{P} \quad=\quad$ The price of input and output in the integration of crop farming + beef cattle breeding

$\mathrm{Q}=$ Output produced from the integration of crop farming + beef cattle breeding

$\mathrm{n}=$ Total of output; There were many kinds of output. These were:

$\mathrm{i} \quad=1,2,3 \ldots . . \mathrm{n}$ (number and kind of output to receive)

$\mathrm{j}=1,2,3, \ldots . \mathrm{m}$ (number and kind of input to use)

1. Earning from crop farming

2. Earning from the difference of cattle purchase and sale prices

3. Earning from the sale price of organic fertilizers

$\mathrm{X}=$ Input used in the integration of crop farming + beef cattle breeding

$\mathrm{M}=$ Type and number of input to be used

\section{Several costs were needed in crop farming, such as the cost for:-}


1) Seeds: rice, corn, soybean, and peanut.

2) Workers

3) Inorganic fertilizers.

4) Organic fertilizers.

Several costs in beef cattle breeding were those for:-

1) Cattle origins.

2) Workers for preparing the feed and maintaining cattle.

3) Greens, straws and others.

4) Concentrates.

5) Analysis of Linear Programming

Maximizing the function of goal;1-

$\operatorname{Max} . Z=\sum_{i=1}^{3} \sum_{j=1}^{3} y_{i j} X_{i}+y X_{4}-\sum_{i=1}^{3} w_{i} X_{4+i}-w X_{8}$

Function of constraint:

Land

$\sum_{i=1}^{3} a_{i j} X_{i} \leq A_{j}$

Seed Availability

$\sum_{i=1}^{3} b_{i j} X_{i} \leq B_{i j}$

Fertilizer

$\sum_{i=1}^{3} \sum_{k=1}^{4} c_{k i j} X_{i} \leq C_{k j}$

Cattle feed

$\sum_{i=1}^{3}-d_{i j} X_{i}+d X_{4} \leq 0$

Workers

$\sum_{j=1}^{3} e_{i j} X_{i}+e_{j} X_{4}-X_{4+j}-X_{8} \leq E_{j}$

Working Capital

$\sum_{j=1}^{3} f_{i j} X_{i}+e_{j} X_{4} \leq F_{j}$

Note:-

$\mathrm{i}=\quad$ crop species (soybean, corn, rice)

$\mathrm{j}=\quad$ planting season (MK I, MK II, MH I)

$\mathrm{k} \quad=\quad$ fertilizer type (Urea, SP-36, Phoska, Organic)

$\mathrm{y}_{\mathrm{ij}} \quad=\quad$ gross earning of crop $\mathrm{i}$ at planting season $\mathrm{j}$ (thousand rupiahs)

$\mathrm{y}=\quad$ gross earning of beef cattle breeding (thousand rupiahs)

$\mathrm{w}_{\mathrm{i}} \quad=\quad$ wage of workers for each crop farming (thousand rupiahs / HOK)

$\mathrm{w} \quad=\quad$ wage of workers in beef cattle breeding (thousand rupiahs / HOK) 


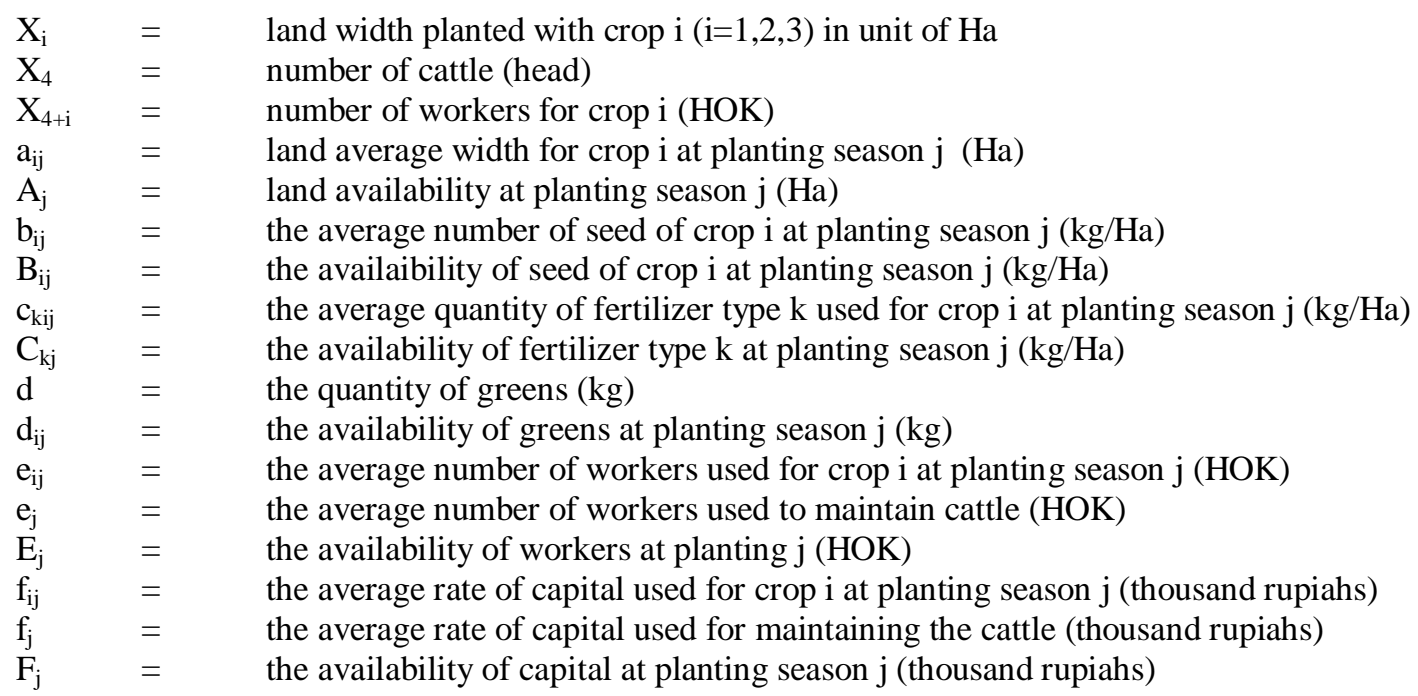

Based on the equation above, the analysis was done using Program Operational Management (POM). Result of analysis reflected the contribution of crop farming and beef cattle breeding to the earning of farmers.

Analysis of Averagely Differential Rate (t-test):-

$\mathrm{H}_{0}: \mathrm{X}_{1}=\mathrm{X}_{2}$

$\mathrm{H}_{\mathrm{A}}: \mathrm{X}_{1}>\mathrm{X}_{2}$

Note : $\quad \mathrm{X} 1=$ earning of farmers after optimization.

$\mathrm{X} 2$ = earning of farmers before optimization.

Statistic equation of t-test was described as following.

$\mathrm{t}-\mathrm{hit}=\frac{\bar{X}_{1}-\bar{X}_{2}}{\sqrt{\frac{\left(n_{1}-1\right) S_{1}^{2}+\left(n_{1}-1\right) S_{2}^{2}}{n_{1}+n_{2}-2}\left[\frac{1}{n_{1}}+\frac{1}{n_{2}}\right]}}$

Note :-

Analysis of Sustainability:-

The analysis technique was Multi Dimentional Scaling (MDS). All attributes in each dimension were assigned into an application program of Microsoft Excel, and then, these were analyzed with MDS using an application Excel for Rapfish.

Table1:-The Category of Sustainability Status

\begin{tabular}{|c|c|l|l|}
\hline No. & Dimension Index & Category & Note \\
\hline 1 & $00.00-24.99$ & Poor & Less sustainable \\
\hline 2 & $25.00-49.99$ & Less & Less sustainable \\
\hline 3 & $50.00-74.99$ & Adequate & Quite sustainable \\
\hline 4 & $75.00-100.00$ & Good & Sustainable \\
\hline
\end{tabular}

Source : Pitcher (1999) and Kavanagh and Pitcher (2004). 
Result And Discussion:-

Beef Cattle Breeding:-

Table 2:-Beef Cattle Breeding (Fattening) per Head per Year.

\begin{tabular}{|l|l|r|c|}
\hline \multicolumn{1}{|c|}{ No } & \multicolumn{1}{|c|}{ Component } & Beef Cattle Breeding & Note \\
\hline A & Average Cost (Rp) & $13,425,000$ & Including stall costs. \\
\hline B & Average Earning (Rp) : & & \\
\hline & (a) Principal (Cattle) & $16,250,000$ & \\
\hline & (b) Waste (Dung) & 657,000 & Dung was well done. \\
\hline & Total & $16,907,000$ & \\
\hline C & Average Income (B-A) & $3,482,000$ & \\
\hline & R/C & 1,26 & \\
\hline
\end{tabular}

Earning obtained from the sale of 1 cattle was Rp. 16,250,000.-. This price was greatly determined by the quality of cattle during one-year fattening process. The heavier the cattle was the more expensive its price would be. This price was obtained from the average sale price of 1 cattle owned by respondent. Earning was also collected from the welldone dung of the cattle because it was useful for organic fertilizer with meaningful economic value. In the reality, farmers utilized dung/organic fertilizers to their crop farming. If the remaining existed, it would be sold to the needed farmers for the price Rp. 200.- per Kg. Economically, the income of farmers from breeding 1 cattle with oneyear fattening process was Rp. 3,482,000.-. This income was low for farmers because beef cattle breeding was only side job for additional income to their primary work, precisely crop farming.

Table 3:-Crop Farming Per Year with Soybean-Corn-Price Planting Pattern

\begin{tabular}{|l|l|r|r|r|}
\hline No & \multicolumn{1}{|c|}{ Component } & \multicolumn{1}{c|}{$\begin{array}{l}\text { Soybean } \\
\text { Farming }\end{array}$} & \multicolumn{1}{|c|}{ Corn Farming } & \multicolumn{1}{|c|}{ Rice Farming } \\
\hline A & Average Cost (Rp) & $5,320,000$ & $3,970,000$ & $4,294,500$ \\
\hline B & Average Earning (Rp) : & & & \\
\hline & (c) Principal (Crop) & $14,700,000$ & $9,750,000$ & $14,245,000$ \\
\hline & (d) Waste (Barks/Cuts/Straws) & $3,879,000$ & $5,982,000$ & $4,145,000$ \\
\hline & Total: A+B & $18,579,000$ & $15,732,000$ & $18,390,000$ \\
\hline C & Average Income (B-A) & $13,259,000$ & $11,752,000$ & $14,095,500$ \\
\hline & R/C & 3.49 & 3.95 & 4.28 \\
\hline
\end{tabular}

Source : Primary Data were Processed, 2015

The Contribution of Beef Cattle Breeding to Household Farming

Table 3:-The Contribution of the Income from Beef Cattle Breeding to the Income of Household Farming in OneYear Period

\begin{tabular}{|c|c|c|c|c|c|c|}
\hline No & Component & Principal & Waste & Total & $\begin{array}{c}\text { Income } \\
(\mathbf{R p})\end{array}$ & $\begin{array}{c}\text { Contribution } \\
(\%)\end{array}$ \\
\hline A & $\begin{array}{lr}\text { Beef } \begin{array}{r}\text { Cattle } \\
\text { Breeding }\end{array}\end{array}$ & $16,250,000$ & 657,000 & $16,907,000$ & $3,482,000$ & 8.18 \\
\hline B & $\begin{array}{r}\text { Soybean } \\
\text { Farming } \\
\end{array}$ & $14,700,000$ & $3,879,000$ & $18,579,000$ & $13,259,000$ & 31.13 \\
\hline $\mathrm{C}$ & Corn Farming & $9,750,000$ & $5,982,000$ & $15,732,000$ & $11,752,000$ & 27.59 \\
\hline $\mathrm{D}$ & Rice Farming & $14,245,000$ & $4,145,000$ & $18,390,000$ & $14,095,500$ & 33.10 \\
\hline & & $54,945,000$ & $14,663,000$ & $69,608,000$ & $42,588,500$ & 100 \\
\hline
\end{tabular}

Table 4:-The Integration Rate of Beef Cattle Breeding and Farming

\begin{tabular}{|c|l|r|r|r|r|}
\hline \multirow{2}{*}{ No } & \multirow{2}{*}{ Component } & \multicolumn{3}{|c|}{ Waste } & \multirow{2}{*}{ Contribution (\%) } \\
\cline { 3 - 4 } & & Physic (Kg) & Price (Rp) & Value (Rp) & \\
\hline A & Beef Cattle Breeding & 3,285 & 200 & 657,000 & 4.48 \\
\hline B & Soybean Farming & 8,620 & 450 & $3,879,000$ & 26.45 \\
\hline C & Corn Farming & 9,970 & 600 & $5,982,000$ & 40.79 \\
\hline D & Rice Farming & 8,290 & 500 & $4,145,000$ & 28.28 \\
\hline & Total & & & $\mathbf{1 4 , 6 6 3 , 0 0 0}$ & $\mathbf{1 0 0 . 0 0}$ \\
\hline
\end{tabular}


The Optimization of Farming and Breeding:-

Table 5:-Primary Activity in the Optimum Integration between Farming and Breeding

\begin{tabular}{|c|l|c|c|}
\hline No. & \multicolumn{1}{|c|}{ Activity } & Unit & Optimum Rate \\
\hline 1 & Planting the soybean at dry season MK I & $\mathrm{Ha}$ & 5.381 \\
\hline 2 & Planting the corn at dry season MK II & $\mathrm{Ha}$ & 6.667 \\
\hline 3 & Planting the rice at rainy season MH I & $\mathrm{Ha}$ & 6.667 \\
\hline 4 & Maintaining the cattle & Head & 21 \\
\hline
\end{tabular}

In addition to the planting, to achieve the optimum farming pattern, it would need resources to support farming activity. These resources were also useful in farming and breeding, such as land, seed, fertilizers (Urea, SP-36, Phoska and Organic), workers, and capital.

Table 6:-The Use of Land Resource at the Optimum Farming Pattern

\begin{tabular}{|c|l|c|c|}
\hline No. & \multicolumn{1}{|c|}{ Activity } & Unit & Optimum Rate \\
\hline 1 & Soybean & $\mathrm{Ha}$ & 5.381 \\
\hline 2 & Corn & $\mathrm{Ha}$ & 6.667 \\
\hline 3 & Rice & $\mathrm{Ha}$ & 6.667 \\
\hline
\end{tabular}

Table7:-The Use of Worker Resource at the Optimum Farming Pattern

\begin{tabular}{|c|c|c|c|c|}
\hline No. & Workers (HOK) & MK I & MK II & MH I \\
\hline 1 & Available & 6,100 & 6,100 & 6,100 \\
\hline 2 & Used & 559 & 298 & 298 \\
\hline 3 & Remaining & 5,541 & 5,802 & 5,802 \\
\hline
\end{tabular}

Post-Optimum Analysis:-

If the optimum pattern of farming and breeding was succesfully achieved by farmers at research area, then their income would be greater. It was said so because the reallocation of resources was more efficient. The income obtained from the optimum pattern scenario was estimated to Rp.531,085,000.- per year. Actual income rate was Rp. 486,553,100.- per year. Or, in other words, if optimum pattern was achieved, then the increment of income would be $9.15 \%$ of actual income. To ensure whether there was actual difference between income in optimum pattern and actual income, t-test was conducted on the average difference of two populations. By considering optimum condition and actual condition as two different populations. Result of t-test could be seen in the following table.

Table8:-Result of t-test on Income Difference from Optimum Condition and Actual Condition

\begin{tabular}{|l|c|c|c|c|}
\hline \multicolumn{1}{|c|}{ Explanation } & $\begin{array}{c}\text { Income } \\
(\mathbf{R p ~ 0 0 0})\end{array}$ & Differential & t-count & t-table \\
\hline Optimum Condition $\left(\mu_{\mathrm{Opt}}\right)$ & 531,085 & $44,531.9$ & $\mathbf{4 , 4 5 3}$ & $\mathbf{2 , 0 4 2}$ \\
\hline Actual Condition $\left(\mu_{\mathrm{Akt}}\right)$ & $486,553.1$ & & & \\
\hline
\end{tabular}

The hypotheses tested in this analysis were:-

Ho : $\mu_{\mathrm{Opt}} \leq \mu_{\mathrm{Akt}}$

Ho : $\mu_{\mathrm{Opt}}>\mu_{\mathrm{Akt}}$

Criteria of Decision : Ho was rejected if t-count $>t$-table

As the table showed, it was known that $\mathrm{t}$-count $=4.453$ and $\mathrm{t}$-table $=2.042$ or, in other words, $\mathrm{t}$-count $>\mathrm{t}$-table, which thus, the decision was that Ho was rejected. Therefore, it was concluded that statistically, the income at optimum condition was greater than actual income of the farmers. The implementation of optimum condition scenario was very recommended to be applied at research area.

Analysis of Sustainability;-

Table9:-Summary of Result of Analysis on MDS-Rapfish

\begin{tabular}{|l|c|c|}
\hline \multicolumn{1}{|c|}{ Dimensions } & Stress (S) & R-Square (R) \\
\hline Ecology & 0.1569 & 0.9347 \\
\hline Economy & 0.1596 & 0.9335 \\
\hline Socio-culture & 0.1459 & 0.9429 \\
\hline
\end{tabular}




\begin{tabular}{|l|l|l|}
\hline Technology and Infrastructure & 0.1584 & 0.9316 \\
\hline Law and Organization & 0.1652 & 0.9412 \\
\hline
\end{tabular}

\section{Dimension of Ecology:-}

Result of MDS analysis on sustainability status in ecology dimension was plotted in Figure 1, while sensitivity (leverage) of each atribut in ecology dimension was shown in Figure 2.

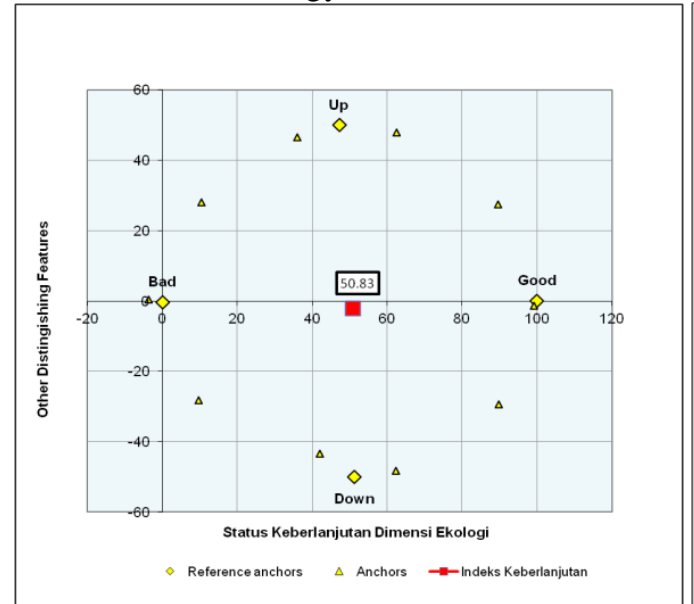

Figure 1:-Sustainability Status of Ecology Dimension. Dimension

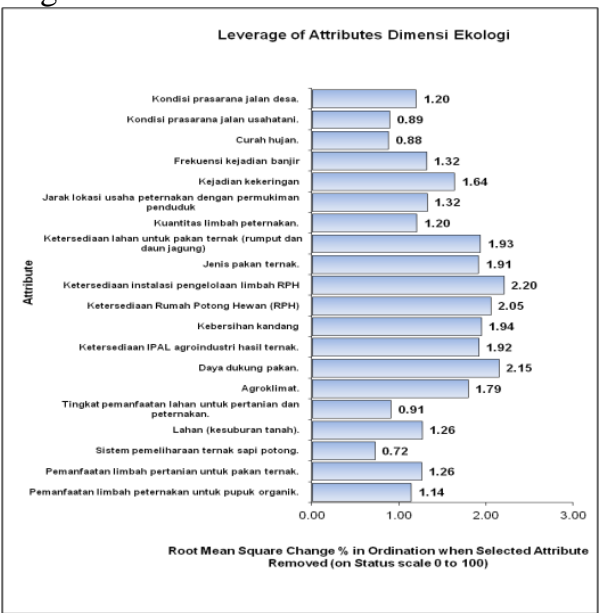

Figure2:-Sensitivity of Attributes in Ecology

Figure 1 indicated that sustainability status index of ecology dimension was 50.83. This rate remained at the range 50-74.99 which meant as adequately sustainable. In other words, the ecology condition in research area was quite supportive to the sustainability of agribusiness with the integration system between cattle and crop.

As shown in Figure 2, some attributes of ecology dimension were quite influential to the sustainability of the dimension, among others were the availability of processing site for RPH waste, the availability of RPH, and the supporting capacity of the feed. It was said so because the leverage rate of three attributes was greater than other attributes. It could be also said that to improve the sustainability of ecology dimension, then the abattoir must be available, nearby, and managed well, with easier access to the feed source.

Dimension of Economy:-

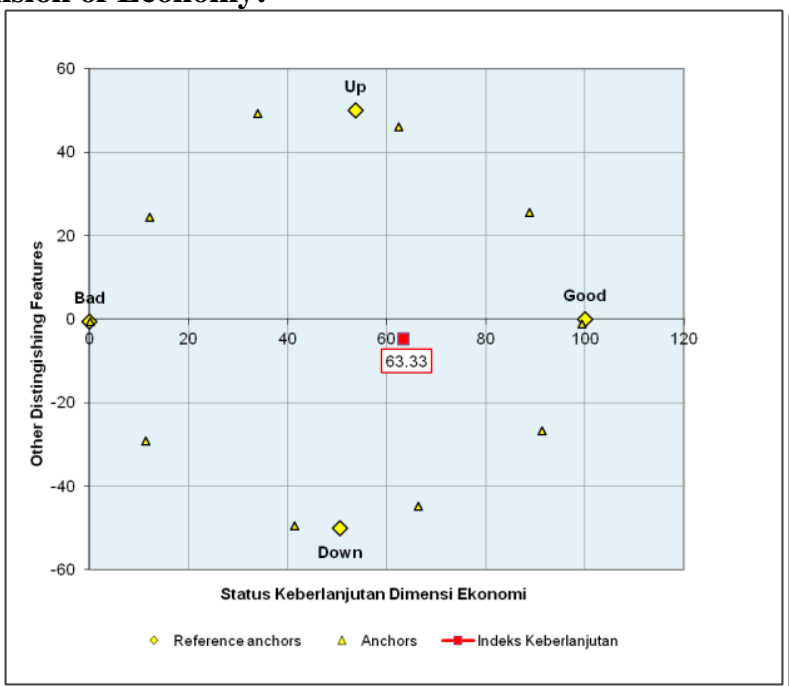

Figure 3:- Sustainability Status of Economy Dimension. Dimension

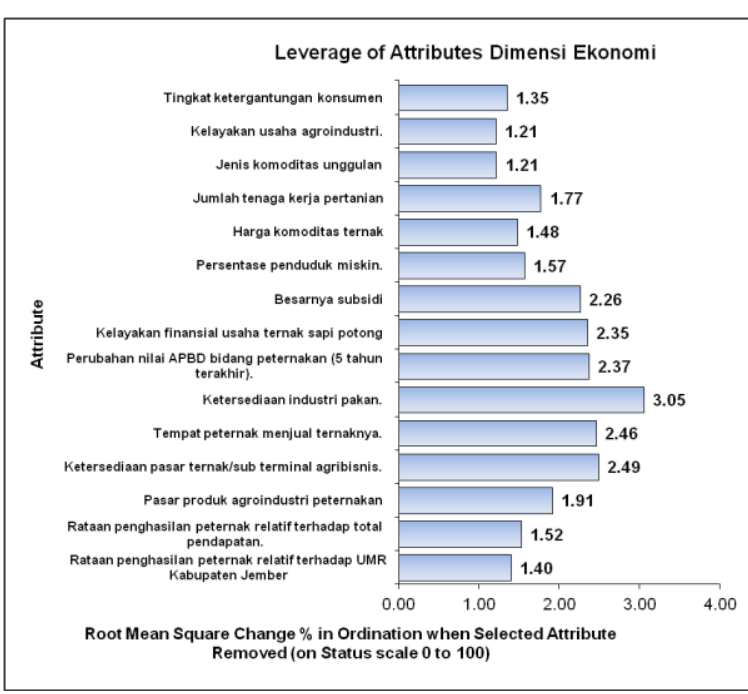

Figure 4:- Sensitivity of Attributes in Economy 
Figure 3 displayed that sustainability status index of economy dimension was 63.33 which put this rate at the range $50-74.99$. In other words, the sustainability was adequate. It was also meant that the agribusiness work with the integration system between cattle and crop at research area was quite profitable in term of economy. Although beef cattle breeding and crop farming quite economically meaningful, to preserve this position or improving it, some attributes must be given great attention because it gave great impact on economy dimension. As noted in Figure 4, some attributes that influenced the sustainability of economy dimension were the availability of feed industry, and the availability of livestock market or agribusiness sub-terminal as the place for breeders to sell the livestock.

\section{Dimension of Socio-culture:-}

Result of MDS analysis on the sustainability status of socio-culture dimension was indicated in Figure 5, while sensitivity (leverage) of each atribut in socio-culture dimension was shown in Figure 6.

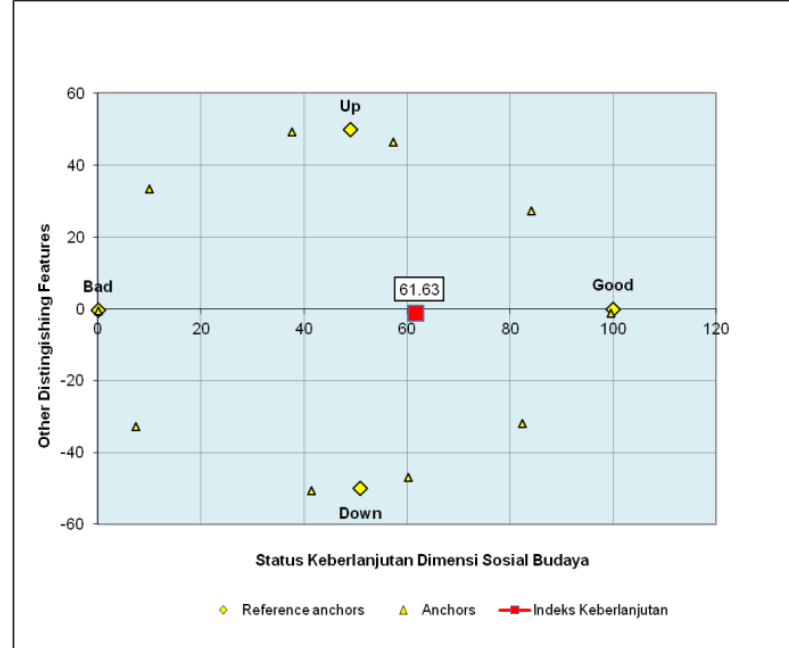

Figure 5:-Sustainability Status of Socioculture Dimension.

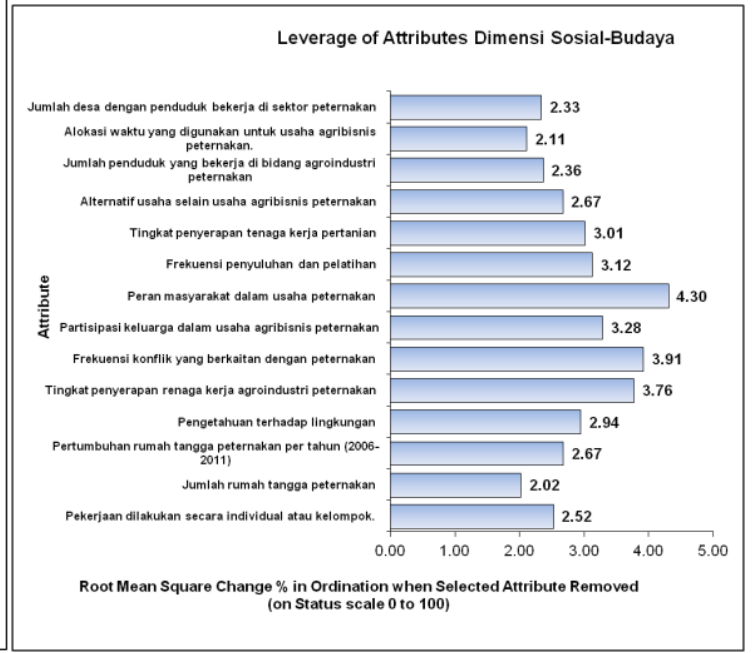

Figure 6:- Sensitivity of Attributes in Socioculture Dimension

Figure 5 indicated that the sustainability status of socio-culture dimension was 61.63 . This index stood at the range of 50-74.99 meaning that this dimension was adequately sustainable. In other words, the social and cultural conditions of research area were adequately supportive to the existence of agribusiness work involving the integration system between cattle and crop. This work was the legacy inherited by generations. Most lands were owned by farmers/breeders as the legacy. Figure 6 showed that the attributes with great influence on the sustainability of socio-culture dimension included the participation of community into breeding work, the frequency of conflict, and the worker absorpance rate. This result of the analysis meant that although breeding and farming were greatly supported in research area, but this work did not sufficiently absorp workers. If such condition was neglected, the long-term sustainability of breeding/farming would be on the risk.

Dimension of Technology and Infrastructure:-

Output of MDS Analysis on sustainability status of technology and infrastructure dimension was displayed in Figure 7, whereas sensitivity (leverage) of each atribute in technology and infrastructure dimension was shown in Figure 8. 


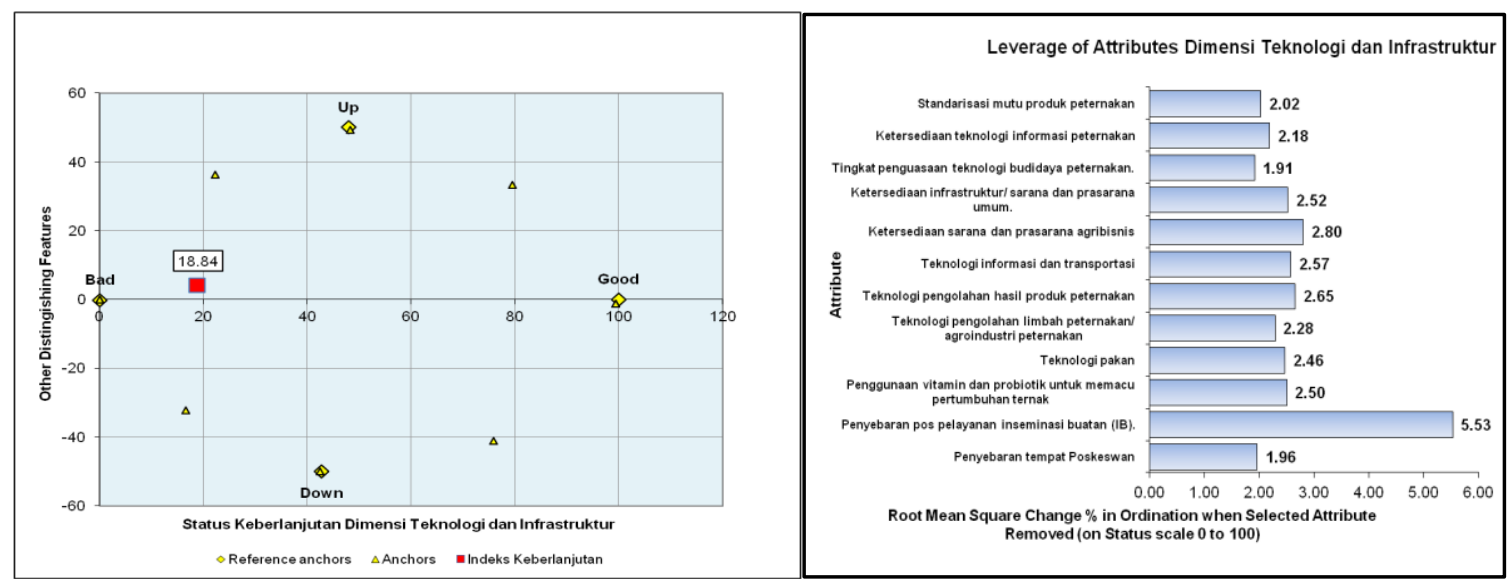

Figure 7:- Sustainability StatusFigure 8:-Sensitivity of Attribute

As shown in Figure 7, the sustainability status index was 18.84. This index was positioned at the range of 0.00-19.99 meaning as not sustainable. It occured because in general, breeders/farmers still used traditional method to manage their work. Result of analysis also showed that if this condition was not improved or just keeping obstinate to use traditional method, then the agribusiness involving the integration system between cattle and crop would be hardly developed because it might be less competitive due to the lack of the availability of technology and infrastructure. As displayed in Figure 8, some attributes were very influential to the sustainability of technology and infrastructure dimension, and these were the distribution of artificial-insemination service post, the availability of agribusiness structure and infrastructure, and the availability of livestock product processing technology (post-production). In other words, the improvement of sustainability status of technology and infrastructure dimension could be focused on the provisioning of artificial-insemination service post, and by making available the structure and infrastructure that supported breeding acitivity, such as livestock extension house and others. Also, post-production technology for breeding could also mprove the agribusiness that involved the cattle-crop integration system.

Dimension of Law and Organization;-

Result of MDS analysis on the sustainability status of law and organization dimension was plotted at Figure 9.

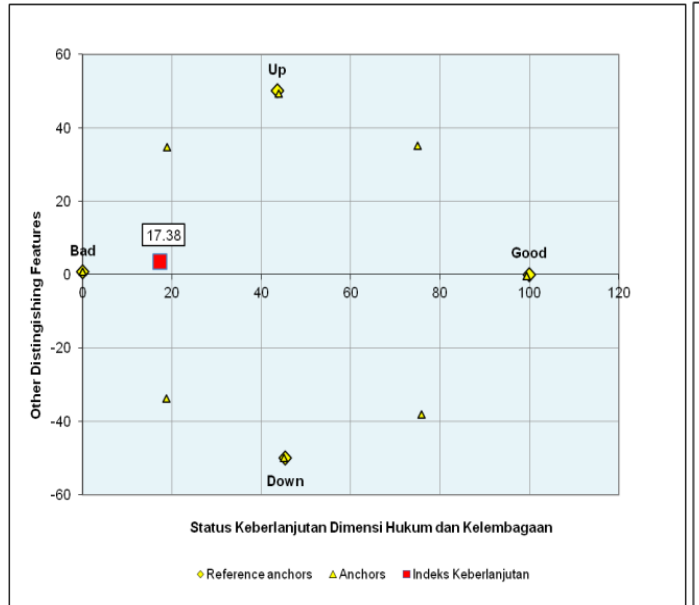

Figure 9:- Sustainability Status of Law and Organization Dimension Law and Organization Dimension

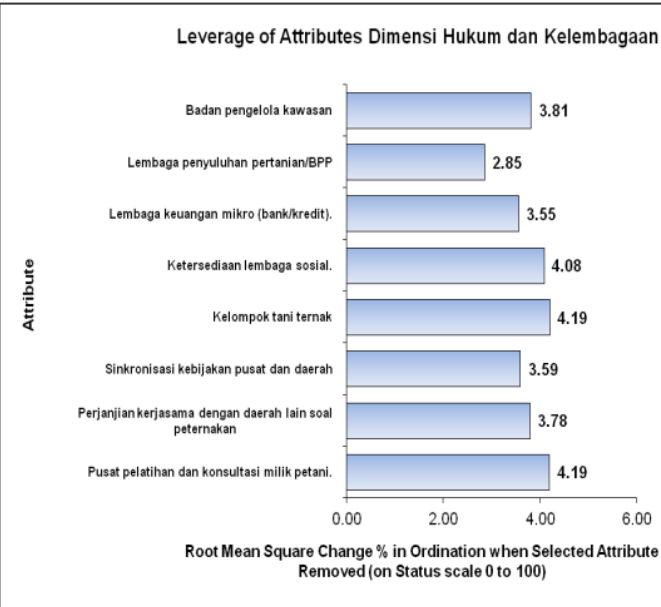

Figure 8:- Sensitivity of Attribute of

Figure 9had shown that sustainability status index of law and organization dimension was 17.38. It remained at the range of 0.00-19.99, meaning that the dimension was not sustainable. It could be said that the support of government and immediate agencies to the agribusiness with cattle-crop integration system was still lacking. Attributes influencing greatly to the sustainability of this dimension was presented in Figure 10. As shown by this figure, there were eight attributes to measure law and organization dimension. In general, its leverage rate was almost similar or 
considered as balancing. There were eight attributes that must be attended to improve the sustainability of law and organization dimension. Those with the highest leverage were the presence of breeder group, the presence of training and consultation center, and the presence of relevant social agency.

The combination of all five dimensions would be useful in measuring the sustainability of agribusiness involving cattle-crop integration system. This sustainability rate of this combination was shown in Figure 11.

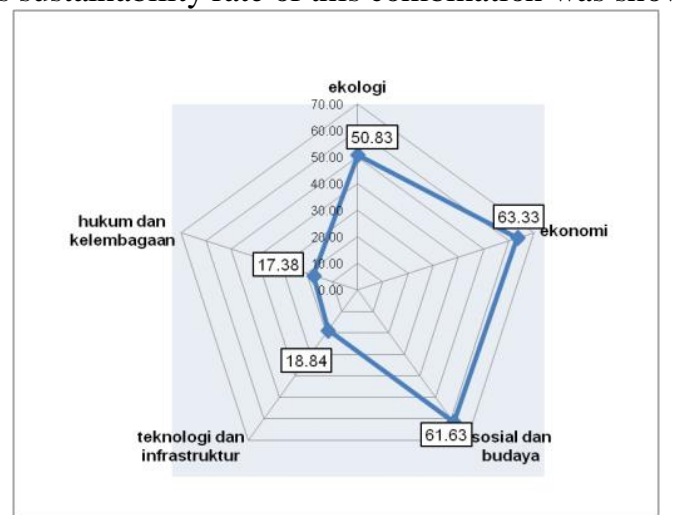

Figure 11:-Kite Diagram of Sustainability Status of The Model of Agribusiness with Cattle-Crop Integration System

In average, the sustainability index rate of the agribusiness involving cattle-crop integration system in research area was 42.40, or in the range of 25.00-49.99 (less sustainable). As shown in kite diagram, if the index went out the diagram or approached to 100 , it meant that sustainability status was better. Conversely, when it stayed inside diagram or went to the proximity of 0 , the sustainability status would be worse. Of five dimensions explained, the dimension with the worst sustainability status was the dimension of technology and infrastructure, and the dimension of law and organization, with each sustainability status of 18.84 and 17.38 (meaning as not sustainable).

\section{Conclusion And Suggestion:- \\ Conclusion;-}

Based on the result of research and discussion, it was concluded in the following:

1. Result of analysis on sustainability status was described:

a. In term of dimension of ecology, the agribusiness with cattle-crop integration system was quite sustainable with the sustainability index of 50.83. The important attributes included the processing of RPH waste, the availability of RPH, and the supporting capacity of the feed. The economy dimension was also quite sustainable with the index of 63.33 , where the sensitive atributes were the availability of feed industry, the availability of livestock market, and the availability of place to sell the livestock.

b. Socio-culture dimension had sustainability index of 61.63 which meant as quite sustainable. The influential attributes were the role of community in livestock business, the frequency of conflict, and the worker absorbance rate.

c. Technology and infrastructure dimension was not sustainable with sustainability index of 18.84 . The sensitive attributes included the presence of artificial-insemination service post, the availability of agribusiness structure and infrastructure, and the availability of livestock product processing technology (post-production).

d. Law and organization dimension had sustainability index of 17.38. The influential attributes were the presence of breeder group, the presence of training and consultation center, and the presence of relevant social agency.

2. The model of optimization and sustainability of the agribusiness with cattle-crop integration system would be helpful in the formulation of policies for the interest of breeders because it allowed breeders to apply sustainable integration system. The combination of five dimensions of sustainability was used to measure the sustainability of agribusiness work with cattle-crop integration system. In whole, based on these five dimensions of sustainability, the agribusiness work with cattle-crop integration system at research area had the sustainability index rate of 42.40 . This index justified the fact that agribusiness work was less sustainable. Dimension with the worst sustainability index, and must be seriously attended, included the dimension of technology and infrastructure and also the dimension of law and organization. 


\section{Suggestion:-}

1. Beef cattle breeding contributed to the income of farmers at relatively smaller degree if compared to the farming activities. Based on the result of Linear Programming Analysis, and in order to achieve the optimum condition, the people of Tegalwangi Village was suggested to bred beef cattle in number of 21 cattles. The number on breeder was more than this suggested number. Therefore, to improve the contribution to farmers' income, then breeders could be educated to manage their breeding in more efficient and effective ways. It should be done to keep cattles providing better input or income.

2. It was also suggested that educating farmers in relative to their breeding method must be important, at least to achieve the optimum condition as shown by the result of analysis of Linear Programming. The increase of farmers' income from beef cattle breeding was also significant.

3. More attentions should be given to the improvement and the availability of technology, infrastructure and organization in research area, which would keep cattle-crop integration system more sustainable.

\section{References:-}

1. Adnyana. 2003. Pengkajian dan Sintesis Kebijakan Pengembangan Peningkatan Produktivitas Padi dan Ternak (P3T) ke Depan. Laporan Teknis Pusat Penelitian dan Pengembangan Tanaman Pangan, Litbang Pertanian, Bogor.

2. Agung, I Gusti Ngurah. 2006. Statistika Penerapan Model Rerata Sel Multivariat dan Model Ekonometri dengan SPSS. Jakarta : Yayasan SAD Satria Bhakti. 